\title{
BEDROCK GEOLOGIC MAP OF THE ROCHESTER QUADRANGLE, RUTLAND, WINDSOR, AND ADDISON COUNTIES, VERMONT
}

\author{
By Gregory J. Walsh and Christine K. Falta
}

\section{INTRODUCTION}

The bedrock geology of the Rochester quadrangle consists of Middle Proterozoic basement gneisses of the Green Mountain massif and Late Proterozoic to Cambrian metasedimentary and metavolcanic cover rocks to the east. The cover rocks underlie most of the quadrangle where they flank the basement rocks on the northeastern side of the northern terminus of the Green Mountain massif and are herein referred to as the eastern cover sequence. Previously, the eastern cover sequence was considered to be a continuous eastward-dipping and -younging stratigraphic section deposited unconformably upon the basement as defined, for example, by Doll and others (1961). The section includes, from west to east, the Tyson, Hoosac, Underhill. Pinney Hollow, Ottauquechee, and Stowe Formations. Recent workers in Vermont, however, have interpreted most of the contacts between formations as faults, and, therefore, the eastern cover sequence is not a single continuous sequence of formations. In the Rochester quadrangle, the formations that comprise the cover sequence are interpreted as juxtaposed by faults in most exposures, therefore, the stratigraphic succession of the formations is uncertain.

Recent studies to the south (Walsh and Ratcliffe, 1994: Ratcliffe, 1992, 1995) and to the north (Walsh, 1992: Armstrong, 1992; Falta, 1991; O'Loughlin and Stanley, 1986; Lapp and Stanley, 1986; DelloRusso and Stanley, 1986) have shown that the cover sequence east of the Green Mountain massif is never at any one place a continuous, nonfaulted stratigraphic sequence, but a series of stacked fault slices. This report represents a link between the recent mapping by University of Vermont workers in central Vermont and mapping by the U.S. Geological Survey in south-central and southern Vermont.

Apart from the Centennial Geologic Map of Vermont (Doll and others, 1961), no geologic maps have been published that cover the entire area in the 7.5-minute Rochester quadrangle. The geology mapped by Dale (1915) represents the earliest work to specifically describe some of the rocks in the quadrangle. Dale's work focused on the carbonates in the area and he briefly mentions the rocks west of Emerson. Foye (1918) spent one month during the summer of 1917 and divided the rocks of the 15-minute Rochester quadrangle into conglomerates and arkoses, quartzites, carbonates, schists, and gneisses. Philip Osberg's (1952) work in the northern half of the 15-minute Rochester quadrangle, north of this 7.5-minute quadrangle, included the first map and detailed discussion of the stratigraphic framework and structural relations in the area. Unpublished reconnaissance work by Osberg was used by J.B. Thompson,
Jr., to compile the geology of the 7.5-minute quadrangle for the State map by Doll and others (1961).

The results of this report represent mapping by Walsh in 1993 and 1994, and by Falta in the northeastern corner of the quadrangle in 1988. The work by Falta extends northward into the 7.5-minute Hancock quadrangle and was completed as part of a Master of Science thesis project at the University of Vermont (Falta, 1991).

\section{ACKNOWLEDGMENTS}

Mapping by Christine K. Falta (1991) was funded through a grant from the National Science Foundation (NSF-EAR 8516979) awarded to Rolfe S. Stanley at the University of Vermont.

\section{STRATIGRAPHY}

\section{ROCKS OF THE GREEN MOUNTAIN MASSIF}

\section{Mount Holly Complex}

Middle Proterozoic basement gneiss and quartzite of the Mount Holly Complex are exposed in the southwestern corner of the quadrangle on the eastern flank of the Green Mountain massif. Ratcliffe and others (1991) have demonstrated a Middle Proterozoic age for the Mount Holly Complex. Exposures of the Mount Holly Complex crop out mainly in Townsend Brook and consist largely of biotite-chlorite-muscovite-quartz-plagioclase gneiss $(\mathrm{Ymh})$ and quartzite $(\mathrm{Yq})$. The gneiss is well layered and the quartzite is somewhat layered, and both are believed to have a sedimentary origin. Locally the quartzite has a finegrained sugary texture that contains highly deformed, disarticulated fragmental quartz. The fragmental nature of the quartzite gives the rock a pebbly or conglomeratic appearance. The presence of interlayered gneiss and disarticulated pegmatites indicates that the rock is basement quartzite, but the deformation has produced a "pseudo-conglomerate" texture; a texture also noted by Brace (1953) in the Rutland area. The quartzite contains accessory muscovite, biotite, chlorite, magnetite, garnet, and plagioclase. Both the gneiss and quartzite contain numerous, small, disarticulated lenses of granitic pegmatite that locally contain coarse books of muscovite and randomly oriented tourmaline that are too small to map individually. The units are assigned to the Mount Holly Complex because they closely resemble similar rocks described by Ratcliffe (1992) in the Mount Holly and Ludlow quadrangles. The gneiss is assigned the designator Ymh but may correlate with Ratcliffe's biotite 
gneiss (Ybg) although it does not contain any interlayered amphibolites. Additional work in the adjacent quadrangles to the south and west where more basement rocks are exposed will help define these correlations.

\section{ROCKS OF THE EASTERN COVER SEQUENCE}

\section{Age of the Eastern Cover Sequence}

The exact age of the rocks in the eastern cover sequence is uncertain largely due to the dearth of fossils and to the presence of faults which prohibits direct correlation with rocks of more certain age. The age of the sequence is believed to range from Late Proterozoic to Ordovician (Walsh and Aleinikoff, 1999; Ratcliffe and others, 1999). Outside the Rochester quadrangle, Late Proterozoic mafic dikes cut the Middle Proterozoic basement rocks, but in turn are cut by the basal unconformity (DelloRusso and Stanley, 1986). The dikes are interpreted as feeders to rift-related mafic volcanic rocks in the eastern cover sequence (DelloRusso and Stanley, 1986; Coish and others, 1985, 1986; Coish, 1987) and, therefore, provide an approximate Late Proterozoic age to all rift-related cover sequence rocks that contain such volcanic rocks. A U-Pb zircon age of $571 \pm 5 \mathrm{Ma}$ indicates a Late Proterozoic age for the Pinney Hollow metafelsite (€Zphf) at exposures on Austin Hill (Walsh and Aleinikoff, 1991). The $571 \mathrm{Ma}$ date is the only age from the rift-related volcanic rocks in Vermont. Kumarapeli and others (1989) indicate a $554 \mathrm{Ma}$ age for rift volcanics in the Tibbit Hill Formation in southern Quebec. The age of volcanism, therefore, appears to be Late Proterozoic. The upper age limit on the rift-related rocks is not well constrained, however, and the rocks may range into the Cambrian. The correlation between graphitic phyllites and schists in the area with Cambrian rocks of the Taconic sequence (Zen, 1967; Potter, 1972; Rowley and others, 1979) provides an approximate age limit for these rocks. The largely noncarbonaceous rocks of the Tyson, Fayston, and Pinney Hollow Formations therefore are assigned a Late Proterozoic to Cambrian age, and the carbonaceous rocks in the Ottauquechee Formation are assigned a Cambrian age. The Stowe Formation was originally assigned a tentative Ordovician age based on the interpretation that it was stratigraphically above the Cambrian Ottauquechee Formation (Cady, 1956). The more recent identification of major faults between the Ottauquechee and Stowe and a correlation with the lithically similar Pinney Hollow Formation lead to the interpretation that the Ottauquechee tectonically overlies the Stowe, and that the Stowe could be as old as Late Proterozoic (Stanley and others, 1987). The lack of stratigraphic continuity and the presence of faults between the Ottauquechee and Stowe question the assignment of a strictly Ordovician age to the Stowe Formation. Until a definitive age can be obtained we prefer to correlate the Stowe Formation with the Pinney Hollow Formation and, therefore, assign a Late Proterozoic to Cambrian age. Within the Rochester quadrangle, however, there is no evidence to preclude the possibility that the Stowe may in part be as young as Ordovician. Ultramafic rocks in the cover sequence are assigned a Late Proterozoic to Ordovician age on the basis of interpretations that they may be fragments of old ocean crust or upper mantle created during the formation of the Iapetan ocean basin (Coish and others, 1986) and then later obducted along faults (Stanley and Ratcliffe, 1985) or deposited as olistoliths during the Taconic orogeny (Walsh and Ratcliffe, 1994).

\section{Tyson Formation}

Rocks assigned to the Tyson Formation occupy a small area with limited exposure in the southwestern corner of the quadrangle and correspond approximately with the area shown on the State map (Doll and others, 1961). Here the Tyson consists of rusty to gray-green albite-quartz granofels that locally contains pebbles $(€ \mathrm{Zt})$. Due to the limited exposure, the basal contact with the underlying Mount Holly Complex was not observed in this quadrangle. Mapping to the south in the Pico Peak quadrangle (Walsh and Ratcliffe, 1998) has established that the albite-quartz granofels does not continue as a mappable unit, but disappears between basement quartzite $(\mathrm{Yq})$ to the west and rusty muscovite-quartz schist (€Zfrm) to the east on the western slopes of the Darning Needle. Identical granofels reappears above and to the east of the rusty muscovite schist (€Zfrm) on the southwestern slopes of the Darning Needle, and continues southeast as a mappable unit into the valley of the South Branch of the Tweed River at a point $1.3 \mathrm{~km}$ north of North Sherburne. There the granofels is interbedded with coarse gneiss-cobble conglomerate that is typical of the Tyson Formation to the south in the Killington Peak and Mount Holly quadrangles (Ratcliffe, 1992; Walsh and Ratcliffe, 1994). Although the granofels mapped as Tyson $(€ Z t)$ in this report does not map continuously to the south, it is named Tyson on the basis of the similarity with the rocks to the south and its similar stratigraphic position directly above basement. Ratcliffe (1995) suggests a probable Cambrian and Late Proterozoic(?) age for the rocks of the Tyson Formation in the Killington Peak quadrangle. On the basis of the similarity with the Tyson Formation rocks to the south, an age of Cambrian and Late Proterozoic(?) is assigned to the granofels in the Rochester quadrangle.

\section{Fayston formation (informal usage)}

The name Fayston formation is applied informally to rocks exposed in the western part of the quadrangle between the Tyson Formation and the overlying Pinney Hollow Formation. These rocks are shown on the Vermont State map (Doll and others, 1961) as the Hoosac, Underhill, and Pinney Hollow Formations. A discussion of the stratigraphic nomenclature follows in an attempt to clarify the use of the many names.

Walsh (1989, 1992) defines the major rock types in the Fayston formation as noncarbonaceous schists and granofels of which a silvery green, light-gray- to white-albite-studded, \pm magnetite-chlorite-quartz-muscovite schist constitutes approximately 90 percent of the formation. Typical exposures of the albitestudded schist crop out in French Brook at an elevation of $1,120 \mathrm{ft}$ in the town of Fayston, Vt., in the 7.5-minute Waitsfield quadrangle (Walsh 1989, 1992). The new name was introduced to redefine rocks previously mapped by Cady and others (1962) as Underhill and Hazens Notch Formations. Figure 1 (figure 1 is in this pamphlet; figs. 2-5 are on the plate) shows the correlation of rock types between the Fayston-Buels Gore area (Walsh, 1992) and the Rochester quadrangle. The most abundant rock type (albite-studded schist) and three other rock types (rusty muscovite-quartz schist, carbonaceous albite schist, and chloritoid schist) are common to both areas. In the Fayston-Buels Gore area (Walsh, 1992), the rusty muscovitequartz schist $(€ Z m)$, carbonaceous albitic schist $(€ \mathrm{~g})$, and chloritoid schist (€Za3) are depositionally interlayered with the albitestudded schist (€Zf), but are assigned to different formations. The name Fayston formation is applied informally in the Rochester quadrangle to the albite-studded schist (€Zfab) and 


\begin{tabular}{|c|c|c|}
\hline $\begin{array}{c}\text { Formation and map unit } \\
\text { symbol used in the Fayston- } \\
\text { Buels Gore area } \\
\text { (Walsh, 1992) }\end{array}$ & Rock type & $\begin{array}{c}\text { Formation and map unit } \\
\text { symbol used in the } \\
\text { Rochester quadrangle } \\
\text { (this report) }\end{array}$ \\
\hline 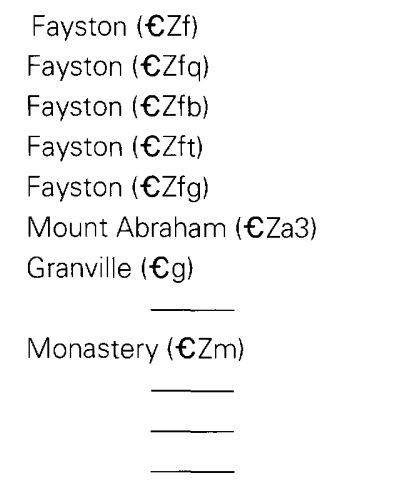 & $\begin{array}{l}\text { Albite-studded schist } \\
\text { Quartz-feldspar granofels } \\
\text { Biotite granofels } \\
\text { Tourmaline schist } \\
\text { Greenstone } \\
\text { Chloritoid schist } \\
\text { Carbonaceous albite schist } \\
\text { Silvery green schist } \\
\text { Rusty muscovite-quartz schist } \\
\text { Pebbly quartzite } \\
\text { Quartzite } \\
\text { Dolomitic quartzite }\end{array}$ & $\begin{array}{l}\text { Fayston (€Zfab) } \\
\text { Fayston }(€ Z f f b) \\
\text { Fayston }(€ Z f c) \\
\text { Fayston }(€ Z f c a b) \\
\text { Fayston }(€ Z f s g) \\
\text { Fayston }(€ Z f r m) \\
\text { Fayston }(€ Z f q c) \\
\text { Fayston }(€ Z f q) \\
\text { Fayston }(€ Z f d q)\end{array}$ \\
\hline
\end{tabular}

Figure 1.-Fayston formation correlation diagram. Rocks mapped as four separate formations in the Fayston-Buels Gore area (Walsh, 1992) are considered to be units of the Fayston formation in this study. _ not recognized in the report.

the less abundant rock types that are associated with the schist. The names Monastery, Granville, and Mount Abraham are not applied in the Rochester quadrangle due to the uncertain distribution of the rock types, and therefore uncertain correlations, in the Bread Loaf and Hancock quadrangles to the west and north.

Osberg (1952) applies the name Monastery Formation to rocks exposed on the northeastern slopes of Monastery Mountain in the Bread Loaf quadrangle. Reconnaissance work by G.J. Walsh (unpub. data) at Osberg's type locality on the northeastern slopes of Monastery Mountain indicates the presence of mappable interlayered (1) rusty. noncarbonaceous schist with interbedded pebbly quartz schist and granofels; (2) green, white-albite-studded schist; (3) chloritoid schist; and (4) minor amounts of rusty, carbonaceous albite schist. The reconnaissance work at Monastery Mountain suggests that the name Monastery was applied by Walsh (1992) to only a small percentage of the rocks that matched Osberg's description at the type locality. The rusty schist with pebbly quartz schist at Monastery Mountain was mapped by Osberg (1952) as Tyson Formation, yet similar rocks were mapped as Hoosac Formation in the Rochester 7.5-minute quadrangle as shown on the State map. Armstrong (1992) applies the name Monastery to undifferentiated albite schist, quartz-feldspar granofels, chloritoid phyllite, quartzite, and dolomite, and raises Osberg's Battell Member of the Monastery to formation status. Thus, recent usage of the name Monastery by Walsh (1992) and Armstrong (1992) is not completely consistent with Osberg's type locality, and some rocks shown on the State map as Hoosac correspond to what Osberg (1952) called the Tyson Member of the Monastery. Presently, it appears that the name Monastery as defined by Osberg may be an appropriate name for some of the rocks mapped as Fayston in the Rochester quadrangle (especially $€ Z$ frm and $€ Z f q c)$. The presence of similar mappable rock types suggests a tentative correlation between some of the rocks mapped as Fayston in this quadrangle with the rocks at Monastery Mountain.

Osberg (1952) applies the name Battell Member of the Monastery Formation to graphitic schists with interbedded dolo- mitic marble, exposed on the southeastern slopes of Battell Mountain and in the Hancock Branch, that are stratigraphically at the top of the Monastery and at the base of the Granville Formation in the Rochester 15-minute quadrangle. Doll and others (1961) interpret the Battell as a member of the Underhill Formation and place it stratigraphically between the Underhill and Pinney Hollow Formations. They map the Battell within the Rochester 7.5-minute quadrangle as a discontinuous belt of rocks that extends from Corporation Brook, across peak 2858, to the vicinity of Hayes Brook. Our map shows that there is a discontinuous belt of carbonaceous albite schist (€Zfcab) in Corporation Brook, yet it contains no carbonate rocks and does not map across peak 2858 to the south. The carbonaceous albite schist (€Zfcab) picks up again east of Knights Hill, crosses West Branch, and continues through the saddle west of Hedgehog Knoll where it is depositionally interlayered at their mutual contact with rusty muscovite-quartz schist (€Zfrm). Doll and others (1961) called the carbonaceous albite schist west of Hedgehog Knoll the Plymouth Member of the Underhill Formation on the basis of a correlation with the carbonates in the town of Plymouth. A thin discontinuous dolomitic quartzite $(€ Z f d q)$ is exposed on the southern side of Hedgehog Knoll; however, this represents the only carbonate rock in the carbonaceous albite schist ( $€ Z \mathrm{fcab})$ seen in the quadrangle. Work in the Pico Peak quadrangle (Walsh and Ratcliffe, 1998) shows that the $€ Z f d q$ and $€ Z f c a b$ units do not map continuously to Plymouth Formation rocks as mapped by Walsh and Ratcliffe (1994) in the Plymouth and Killington Peak quadrangles. In the Pico Peak quadrangle the Plymouth Formation rocks crop out north of North Sherburne where they turn west up the eastern slopes of the Darning Needle but do not continue north into the Rochester quadrangle. Therefore, due to the lack of mappable continuity of these rocks with the Plymouth Formation rocks to the south, the name Plymouth is not used. Where the carbonaceous albite schist ( $€ Z f c a b)$ contains dolomitic quartzite ( $€ Z f d q)$ it corresponds to the boundary between the Pinney Hollow and Fayston formations in the southern part of the quadrangle. Similar dolomitic quartzites and carbonaceous to graphitic 
schists crop out along this boundary in Bingo Brook in the adjacent Mount Carmel quadrangle (Ratcliffe and Walsh, 1998), just 0.5 to $1.0 \mathrm{~km}$ northwest of Kings Pond in the Rochester quadrangle. This evidence suggests a possible correlation with rocks previously mapped as Battell on the State map, but the name is not used due to the uncertain and incomplete understanding of the distribution of these rock types in the adjacent quadrangles to the west and north.

One of the reasons Walsh $(1989,1992)$ introduces the name Fayston is to avoid ambiguity with rocks previously mapped as Hazens Notch and Underhill (Doll and others, 1961; Cady and others, 1962). The Hazens Notch Formation at its type locality contains carbonaceous and noncarbonaceous albite schist with greenstone, amphibolite, and ultramafic rocks at Hazens Notch in Westfield, Vt. (Cady and others, 1963). The presence of ultramafic rocks in the Hazens Notch Formation suggests that these rocks do not correlate with the carbonaceous rocks mapped as Fayston within the Rochester quadrangle. In fact the descriptions sound more like the rocks of the carbonaceous albite schist member (€ocab) of the Ottauquechee Formation. Walsh (1992) uses the name Underhill for coarse, noncarbonaceous feldspathic schists, granofels, and amphibolites, which correlate with Christman and Secor's (1961) western part of the Underhill Formation called the "western sequence." The Underhill Formation of Walsh (1992) is located west of and structurally below the Fayston formation. Thompson and Thompson (1992) assign the name Underhill to a silver-green, white-albite-spotted schist with magnetite and interlayered greenstone. They also redefine the type locality to The Chin on Mount Mansfield, due to the vague description provided by Christman and Secor (1961) in the original definition. We suggest a correlation between the noncarbonaceous white-albitespotted schist of the Underhill and a similar rock in the Fayston $(€ Z f a b)$, but hesitate to use the name Underhill for two reasons. (1) Although the type locality has been redefined (Thompson and Thompson, 1992), the name is ambiguous because the original name applied to many rock types that recent workers (Tauvers, 1982; DiPietro, 1983; DelloRusso and Stanley, 1986; Lapp and Stanley; 1986; O'Loughlin and Stanley, 1986; Thompson and Thompson, 1992; Walsh, 1992) have mapped using many different names including Underhill (for example, Fayston, Hazens Notch, Hoosac, Pinnacle, and Monastery). (2) In the Rochester quadrangle, the location of the western contact between the Underhill and Hoosac Formations as previously mapped (Doll and others, 1961) does not correspond to a boundary between any rock type or lithostratigraphic unit identified in this study.

Recent work to the south of the Rochester quadrangle suggests that the Tyson Formation and the Plymouth Formation laterally replace much of the Hoosac Formation of southern Vermont (Ratcliffe, 1992, 1995; Walsh and Ratcliffe, 1994). At about the latitude of Simonsville $\left(43^{\circ} 16^{\prime} \mathrm{N}\right.$.) in the Andover quadrangle, grits, feldspathic schists, and conglomerates of the Tyson Formation and feldspathic quartzites and dolostones of the Plymouth Formation (Ratcliffe, 1995) occupy the section beneath the Pinney Hollow Formation and above the Mount Holly Complex. Limited exposures of green albite schist and dark-gray albite-biotite schist assigned to the Hoosac Formation occur in contact with both the Tyson and Plymouth Formations in the eastern part of the Killington Peak quadrangle. However, numerous thrust faults that cut the Tyson, Hoosac, and Plymouth Formations in the Plymouth and Killington Peak quad- rangles extend northward through the Pico Peak quadrangle (Walsh and Ratcliffe, 1998) and into the Rochester quadrangle. Because of the evidence for along-strike replacement northward, and because of the complications of faulting, the name Hoosac is not used in this area. Nonetheless, certain rocks of the Fayston formation are identical to rocks in the Hoosac Formation, and the Fayston and Hoosac can probably be broadly correlated.

The major rock type of the Fayston formation in the Rochester quadrangle is the gray-green albite-studded schist (€Zfab). Excellent exposures of the schist are located in the southwestern part of the map on the southern and western ridges of Knights Hill, the western slopes of Wilcox Peak, the summit area of peak 2858, and the saddle just east of peak 2858. The schist is typically medium to coarse grained and forms prominent cliffs and outcrops. Magnetite porphyroblasts occur locally. Layers rich in magnetite, parallel to the oldest compositional layering, and perhaps bedding, are present in outcrops near the confluence of Caryl Brook and the West Branch of the Tweed River. Here, the magnetite was mined for iron ore. The albite schist does contain outcrop-scale layers of fineto medium-grained silvery green schist ( $€ Z \mathrm{fsg})$ that may or may not contain porphyroblasts of albite. Both the albite schist and silvery green schist are lithologically similar to the $€ Z$ phab and $€ Z$ ph rocks in the Pinney Hollow Formation to the east. These rocks are believed to be facies equivalent. Similar findings are reported in central Vermont (Walsh and Stanley, 1988; Walsh, 1989, 1992).

The second major rock type in the Fayston formation is the rusty muscovite-quartz schist ( $€ \mathrm{Zfrm})$ that is exposed on the ridge between peaks 2525 and 2388 and in Townsend Brook between 1,440 and $1,540 \mathrm{ft}$. The $€ Z \mathrm{frm}$ unit contains characteristic rusty weathering spangly muscovite. The unit also contains outcrop-scale layers of pebbly muscovite quartzite and granofels that are mapped as $€ Z \mathrm{fqc}$ where thick enough. The $€ Z$ fqc unit is thickest (approximately $30 \mathrm{~m}$ ) on the eastern side of peak 2525 at an elevation of $2,300 \mathrm{ft}$. A thin exposure of $€ Z f q c$ is located in Townsend Brook just above $1,520 \mathrm{ft}$. The rusty schist is interlayered with the gray-green albite schist (€Zfab) and the carbonaceous albite schist (€Zfcab).

Minor lithologies within $€ Z f a b$ include interbedded biotite granofels (€Zfb) exposed in Corporation Brook above 2,100 ft, the carbonaceous albite schist (€Zfcab) discussed above, and an isolated quartzite ( $€ \mathrm{Zfq}$ ) exposed between 2,400 and $2,500 \mathrm{ft}$ on the ridge southeast of the brook. The quartzite $(€ Z \mathrm{fq})$ resembles quartzite within the Mount Holly Complex $(\mathrm{Yq})$ and contains similar coarse muscovite porphyroblasts. The contacts with the surrounding schist are not clearly exposed, but the rock types are not interlayered. There is no evidence of fault fabrics or truncations, nor are there any unconformable relations. For these reasons, this quartzite has been mapped as a member of the Fayston formation.

The semicontinuous to continuous units on the eastern side of the Fayston formation, east of the Darning Needle fault, appear to be a coherent sequence without any large-scale repetition by folds. In the southwestern part of the formation, however, the units are isoclinally folded about a large $\mathrm{F}_{2}$ antiform with an eastto southeast-trending fold axis. This fold is fault-bounded, and rocks to the east of the Darning Needle fault are apparently not repeated by similar large-scale folds. Topping criteria were not observed in the Fayston formation, and it is uncertain whether the rocks in the antiform are in a syncline or an anticline. Using 
the assumption that the greenstone-bearing rocks in the Pinney Hollow are perhaps slightly older, and using a correlation between the units $€ Z f s g$ and $€ Z \mathrm{ph}$, and $€ Z f \mathrm{f}$ and $€ Z$ phc, we speculate that the antiform is anticlinal. This interpretation requires that the homoclinal sequence on the eastern side of the formation, which appears to be stratigraphically continuous with the Pinney Hollow Formation (see discussion on the Kings Pond belt below), is overturned towards the west, and that a syncline antithetic to the antiform between the Thousand Acre Hill and the Darning Needle faults is missing. This interpretation requires that the rocks east and west of the Darning Needle fault were at one time a continuous sequence. We believe that the rusty schist (€Zfrm) at peaks 2388 and 2525 are correlative, but the intervening synformal sequence is absent due to faulting. Despite the uncertainties concerning the internal stratigraphic order of the Fayston formation, the mapping reveals two distinct structural belts of rocks: (1) an isoclinally folded, fault-bounded sequence in the west and (2) an homoclinal sequence in the east that appears to be stratigraphically continuous with the Pinney Hollow Formation.

\section{Pinney Hollow Formation}

The Pinney Hollow Formation occupies approximately onehalf of the Rochester quadrangle and is exposed in a north- to northwest-striking belt in the center of the quadrangle. Generally, the Pinney Hollow Formation contains slightly different internal stratigraphy and structure across the area. For the purpose of discussion, the formation is subdivided into three belts, which are referred to as, from west to east, the Kings Pond, Mount Reeder, and Emerson belts.

Recent work by Walsh and Ratcliffe (1994) at the type locality of Pinney Hollow in the Plymouth quadrangle indicates a strong correlation between the rock types in both areas. Due to tectonic thinning, or in part from lateral facies changes, the albite schist (€Zphab), feldspathic quartz schist (€Zphq), and feldspathic granofels (€Zphw), however, are not mappable units at the type locality.

Rocks of the Kings Pond belt are bounded by the Fayston formation to the west and by the Little Wilcox Peak fault to the east. The majority of the rocks in the Kings Pond belt consists of silvery green schist ( $€ Z \mathrm{ph})$ and gray-green albite schist (€Zphab). Both rock types are well exposed northeast of Kings Pond in the northwestern corner of the map north of the village of Robinson. The contact between these two units is quite transitional and is marked by a coarsening in texture from $€ Z \mathrm{ph}$ into EZphab which is due largely to the increase in size and abundance of albite porphyroblasts. Chloritoid schist (€Zphc) and black carbonaceous schist (€Zphb) are interlayered largely with the silvery green schist $(€ Z \mathrm{ph})$. The rocks of the Kings Pond belt are a transitional sequence from fine-grained schist and abundant greenstone in the Mount Reeder belt to the east to the coarser grained, more quartzofeldspathic schist lacking greenstone in the Fayston formation to the west. The rocks of the Kings Pond belt are interpreted as a depositionally fining sequence from Fayston to Pinney Hollow rocks. The continuous and semi-continuous units suggest that the rocks in the Kings Pond belt are a homoclinal sequence that is not repeated by large-scale folds. Topping criteria were not observed anywhere in the quadrangle, however, and it is not possible to tell whether the rocks in the Kings Pond belt represent an upright sequence topping to the east (from Fayston up to Pinney Hollow) or an overturned sequence topping to the west (from
Pinney Hollow up to Fayston). The lack of greenstone in the Fayston formation may indicate that the rocks to the west are in part younger than those to the east if one assumes that the greenstones are rift-related and that the post-rift sediments were relatively free of volcanic rock. The possibility of a fault between the Fayston and the Pinney Hollow was considered; however, there is no conclusive evidence of such a fault. Arguments opposed to a fault include the following: (1) Although the carbonaceous albite schist (€Zfcab) pinches out along the contact, it is not truncated, and there are no upper or lower plate truncations, (2) the main rock types (€Zfab, $€ Z p h$, and $€ Z f_{\mathrm{fab}}$ ) are interlayered along the contact, and (3) the distribution of mapped units is parallel to the contact.

Rocks of the Mount Reeder belt are bounded by the Little Wilcox Peak fault to the west and by the Tweed River and White River faults to the east (see cross sections $\mathrm{B}-\mathrm{B}^{\prime}$ and $\mathrm{C}-\mathrm{C}^{\prime}$ ). The internal structure of the Mount Reeder belt is dominated by a large, second generation isoclinal fold that effectively doubles the section in the central part of the Pinney Hollow Formation. The main rock type in the Mount Reeder belt is the silvery green schist (€Zph). The silvery green schist is well exposed on the summit of Mount Reeder and in roadcuts just south of the summit.

The second most abundant rock type is greenstone ( $€ Z$ pha). The greenstone, as much as $200 \mathrm{~m}$ thick locally, forms two belts that converge in the hinge of a large $F_{2}$ fold (see discussion in the section on structure) on the southwestern slopes of Mount Reeder. Excellent exposures of the greenstone are located on the peaks north and south of Liberty Hill and at roadcuts south of Mount Reeder. The greenstone varies from massive to well layered. Overall, the unit is quite heterogeneous and, for the most part, is interbedded with the enclosing schist (€Zph). The heterogeneity and presence of layers of pelitic and calcareous pelitic rocks suggest that much of the greenstone is probably a volcaniclastic deposit. The greenstone contains not only layers of silvery green schist but also calcite schist and marble, and metafelsite.

The laminated calcite schist (€Zphca) is thick enough to map in two places, west of Emerson and north of Pittsfield. On the ridge east of the saddle on Liberty Hill Road, the greenstone is in contact with a calcite marble. Here, a thin transitional calcite schist intervenes between the marble and the greenstone. An identical marble is in sharp contact with the silvery green schist in an outcrop in the Tweed River located approximately $1.1 \mathrm{~km}$ east-northeast of downtown Pittsfield. The presence of these carbonate rocks, especially the marble, is in striking contrast to the majority of Pinney Hollow rocks mapped elsewhere. Dale (1915) reported that a continuous belt of carbonate rocks extended north from Rochester into the town of Hancock along the western side of the White River. This study shows that these rocks are small, isolated lenses of carbonate deposited in a largely clastic sequence.

A metafelsic volcanic or volcaniclastic rock crops out within the greenstone of the Pinney Hollow Formation in the Mount Reeder belt. This is the first reported occurrence of a metafelsite in the Pinney Hollow Formation. The unit, herein named the metafelsite at Austin Hill (€Zphf), is exposed on the southwestern slopes of Austin Hill, and excellent exposures are located at roadcuts along Austin Hill Road in a housing development (Great Hawk Colony-not labeled on map) at an approximate elevation of $1,830 \mathrm{ft}$. The metafelsite is interlayered with the greenstone unit (€Zpha) and, to a lesser extent, the silvery green 
schist (€Zph). Exposures east of Austin Hill Road between the elevations of 1,480 and $1,580 \mathrm{ft}$ contain 1 - to 10 -cm-thick layers of felsic and mafic schist along the contact between $€ Z$ phf and $€ Z$ pha. The interlayering of the rock types suggests that the contact is depositional. Elsewhere, where the contacts are not as clearly exposed, the adjacent rocks include greenstone (€Zpha), calcite greenschist (€Zphca), and fine-grained silvery green schist ( $€ Z \mathrm{ph})$. The metafelsite is interpreted as a tuffaceous sediment or crystal tuff. The metafelsite contains a thin, 1- to 2-m-thick, purplish-gray feldspathic quartzite (€Zphfq) that is well exposed at a roadcut on Austin Hill Road at an approximate elevation of $1,500 \mathrm{ft}$.

Rocks of the Emerson belt are bounded by the Tweed River and White River faults to the west and by the Tupper fault to the east (see cross sections $\mathrm{B}-\mathrm{B}^{\prime}$ and $\mathrm{C}-\mathrm{C}^{\prime}$ ). Structurally, the continuity of the units within the belt suggests that the units are part of a homoclinal sequence without any internal repetition by large-scale folds. Topping criteria were not observed in the Emerson belt, and it is unknown whether the belt tops to the east, or is overturned to the west.

The major rock type in the Emerson belt is the silvery green schist (€Zph). The Emerson belt contains two coarse clastic units (€Zphw and $€ Z$ phq) that are rare or absent in the Kings Pond and Mount Reeder belts (a thin belt of $€ Z$ phw was mapped on the southeastern ridge of Wilcox Peak in the Kings Pond belt). The feldspathic granofels or metawacke (€Zphw) is thickest and best exposed on the ridge north and east of Talcville, and can be traced to the southwestern ridge of Rogers Peak before truncating against the Tupper fault. The feldspathic quartz schist (€Zphq) is best exposed at roadcuts along Route 100 just north of Emerson and at a point $2.4 \mathrm{~km}$ north of Pittsfield. The feldspathic quartz schist is interbedded with the metawacke along the western slopes of Rogers Peak. Greenstone (€Zpha), black carbonaceous to graphitic phyllite and schist (€Zphb), and chloritoid schist (€Zphc) also are present in the Emerson belt; all are exposed along the southern and western ridges of South Hill.

Rocks of the Pinney Hollow Formation are exposed in three belts, each with slightly different internal stratigraphy and structure. Rocks in the western Kings Pond belt and eastern Emerson belt appear to be homoclinal sequences. The Kings Pond is stratigraphically continuous with the Fayston formation to the west, and the Emerson belt is fault-bounded along the contact with the Ottauquechee Formation to the east. The central Mount Reeder belt is isoclinally folded and the internal stratigraphy is effectively doubled. Rocks in the Kings Pond and Emerson belts are significantly different enough to argue against a correlation between the belts as part of a structural repeat about the isoclinal fold in the Mount Reeder belt. Furthermore, the boundaries between the three belts are characterized by faults and shear zones, and although the faults are discontinuous and difficult to trace across the entire quadrangle, their presence helps explain why the stratigraphy is not simply repeated about a fold in the center of the formation.

\section{Ottauquechee Formation}

The Ottauquechee Formation contains two main rock units that are approximately equally abundant. The most distinctive unit consists mostly of graphitic phyllite (€ob), and the other unit consists mostly of carbonaceous albite schist (€ocab). The carbonaceous albite schist is similar to rocks mapped as the Thatcher Brook member of the Ottauquechee Formation by
Falta (1991), Armstrong (1992), and Walsh (1992). The Thatcher Brook member was informally named by Armstrong (1992) for exposures in Thatcher Brook in the town of Granville, located in the 7.5-minute Hancock quadrangle just north of the Rochester quadrangle. The carbonaceous albite schist (€ocab) is correlated with the Thatcher Brook member on the basis of lithic similarities, however, the name Thatcher Brook is not adopted here.

Rocks of the Ottauquechee Formation occur in the Rogers Peak and New Boston slices. The rocks are divided into slices and not belts because of the tectonic nature of the contacts along the boundary of the Ottauquechee Formation. The major rock types in the Rogers Peak slice are carbonaceous albite schist (€ocab) and quartz schist and feldspathic schist (€ogq). The rocks of the Rogers Peak slice are bounded by the Tupper fault along the contact with the Pinney Hollow Formation to the west and by the Rogers Peak fault to the east. The carbonaceous albite schist (€ocab) is a rusty, heterogeneous assemblage of carbonaceous albite schist, noncarbonaceous schist, and thin quartzites. The unit also contains minor amounts of noncarbonaceous gray-green albite schist and graphitic schist. A thin greenstone (€oa) crops out on the ridge east of Tupper. The heterogeneous distribution of minor lithologies within the €ocab unit is unique to this carbonaceous schist unit. Carbonaceous schists to the west in the Pinney Hollow and Fayston formations generally do not contain the minor lithologies, and the distribution of carbonaceous matter is more uniform in the western units.

The quartz schist and feldspathic schist unit (€ogq) consists of noncarbonaceous, gray to green, coarsely laminated rocks. The €ogq unit grades by intercalation into a less quartz-rich, more feldspathic gray-green schist and gneiss (€og) which generally lacks laminations. Both $\epsilon_{\text {og }}$ and $\operatorname{Cog}_{\text {q }}$ contain thin beds of coticule, or spessartine garnet quartzite, indicated by a " $\mathrm{c}$ " on the map. In thin section, the garnet is yellowish brown, somewhat anisotropic, and generally ranges in size from 5 to $10 \mu \mathrm{m}$. The coticule beds are generally 1 to $10 \mathrm{~mm}$ thick and are interlayered with very thin ( 1 to $10 \mathrm{~mm}$ ) gray-green quartzite, rich in epidote and biotite. The best exposure of the coticule beds is in New Boston, approximately $50 \mathrm{~m}$ north of the house at the end of the main road, at an approximate elevation of $1,620 \mathrm{ft}$. The laminated schist (€ogq) is similar to the feldspathic quartz schist in the Pinney Hollow Formation ( $€ Z$ phq). They may be distinguished based upon the following criteria: (1) €Zphq does not contain coticule, (2) €Zphq is interlayered with $€ Z p h w$ and $€ Z$ ph rocks, (3) €ogq is interlayered with €ocab rocks, and (4) €ogq is laterally transitional with and contains layers of $€$ og.

The rocks of the New Boston slice are bounded by the Rogers Peak fault to the west and the Stockbridge-Rochester Gap fault system to the east. The major rock units in the New Boston slice are the carbonaceous albite schist (€ocab), black phyllite (€ob), and gray-green feldspathic schist and gneiss (€og) (see cross section $\left.B-B^{\prime}\right)$.

A recent re-evaluation of the Ottauquechee Formation at the type locality of Perry (1927, 1929) by Walsh and Ratcliffe (1994) indicates that the major rock type is a dark-gray to black, graphitic phyllite to fine-grained schist. Mapping in the Rochester quadrangle demonstrates that the graphitic phyllite is a major rock type in the southern and northern parts of the map, but the carbonaceous albite schist is the major rock unit in the central part of the map. Rocks equivalent to the carbonaceous albite schist are not present at the type locality (Walsh and 
Ratcliffe, 1994). Where the black phyllite (€ob) crops out here, it contains quartzites and quartz schists (€oqb and €oq) that are identical to the rocks at the type locality. A well-exposed black quartzite (€oqb) crops out at an elevation of $1,370 \mathrm{ft}$ in a tributary to Bartlett Brook, approximately $0.6 \mathrm{~km}$ from the southern border of the map. An excellent exposure of the quartz schist (€oq) is located $1.5 \mathrm{~km}$ west of the junction of Routes 100 and 107 , at a Route 100 roadcut approximately 100 m east of the Stockbridge general store. A typical exposure of black phyllite (€ob) and the carbonaceous albite schist (€ocab) is located at a roadcut $2.1 \mathrm{~km}$ north of Stockbridge Village on Route 100. At the northern end, the roadcut exposes carbonaceous albite schist that contains abundant layers of tan and gray quartzite; the southern end exposes rusty to yellow sulfidic-stained black phyllite, typical of the Ottauquechee.

The gray-green feldspathic schist ( $€$ og) is intercalated with rocks of the carbonaceous albite schist (Eocab) and, to a lesser extent, with the black phyllite (€ob). A gray schist, gray-green paragneiss, and gray-green albite schist were mapped by Walsh and Ratcliffe (1994) at the type Ottauquechee. All three rock types are contained within the $\mathrm{Cog}$ unit of this quadrangle.

Falta (1991) originally mapped the gray-green schists in the Ottauquechee Formation ( $€$ og and $€$ ogq) as the Pinney Hollow Formation and, to a lesser extent, the Stowe Formation. A reevaluation of her work led to the re-assignment of some of these rocks to the Ottauquechee Formation. Falta did note, however, that rocks she mapped as Pinney Hollow that are in contact with the carbonaceous albite schist (€ocab) are considerably different than the fine-grained Pinney Hollow rocks located to the west. The four main points that support the assignment of these rocks ( $€$ og and $€$ ogq) to the Ottauquechee Formation are (1) the composition and character of the rocks are unlike Pinney Hollow or Stowe rocks (in fact, they bear more similarity to the albite rock of the Fayston formation, $€ Z f a b),(2)$ the rocks contain coticule which is not present in any other formation in the quadrangle, but is found at the type Ottauquechee in Plymouth (Walsh and Ratcliffe, 1994), (3) they are interbedded with carbonaceous and graphitic schists of the Ottauquechee Formation, and (4) similar rocks are found in the Ottauquechee Formation at the type locality in the Plymouth quadrangle. Fine-grained silvery green schists that resemble the Stowe $(€ Z s)$ and Pinney Hollow rocks ( $€ Z \mathrm{ph})$ do occur within the Ottauquechee Formation and have been mapped as either $€ Z s$ or $€ Z p h$. These units are either depositional layers or fault-bounded slices of Stowe- and Pinney Hollow-like rocks within the Ottauquechee (see discussion in the section on faults).

Greenstones in the Ottauquechee Formation (€oa) crop out within the Rogers Peak and New Boston slices. Thin (5-10 m) greenstones are interlayered with the feldspathic schists of $€$ og and €ogq, and occur to a lesser extent in €ocab. The largest greenstone within the Ottauquechee Formation is located west of the village of Stockbridge. Here, the greenstone is interlayered with €og, €ocab, €om, and €ob rocks and contains an ultramafic body $(\mathrm{OZu})$. At the type locality in the Plymouth quadrangle the greenstones of the Ottauquechee Formation are also interbedded in the enclosing strata (Walsh and Ratcliffe, 1994).

The coarse-muscovite schist unit (€om) is a previously unreported rock type in the Ottauquechee Formation. The rock is exposed in the south-central part of the New Boston slice on the southern ridge of Mount Lympus (in the adjacent Bethel quadrangle) and on the western side of the White River, just west of the abandoned talc-serpentine mines approximately $1.5 \mathrm{~km}$ northwest of the village of Stockbridge. The characteristic feature of this rock is the abundance of coarse (up to $7 \mathrm{~mm}$ ) muscovite porphyroblasts. Locally on the southern ridge of Mount Lympus, the unit contains chlorite pseudomorphs after garnet. The rock is most closely associated with greenstone (€oa). Thin layers of greenstone are interbedded with €om near the abandoned mines northwest of Stockbridge. Here, the unit as a whole is in contact with a large greenstone body and the ultramafic deposit at the mines. On the southern ridge of Mount Lympus fom is again interlayered with a mapped greenstone (€oa) along its western contact. West of the greenstone, rocks of the carbonaceous albite schist (€ocab) crop out and the contact is sharp.

\section{Stowe Formation}

Rocks of the Stowe Formation are exposed in the northeastern and southeastern corners of the quadrangle. They are bounded to the west along the Stockbridge-Rochester Gap fault system where they border the rocks of the Ottauquechee Formation. The eastern boundary of the Stowe Formation, against the Moretown Formation, is not exposed in the Rochester quadrangle.

The major rock type in the Stowe Formation is the silvery green schist (€Zs), which constitutes over 95 percent of the formation, and is similar to the silvery green schist of the Pinney Hollow Formation ( $€ Z \mathrm{ph})$. Extensive exposures of the schist are located at a roadcut along Route 100 just north of the junction with Route 107, on an isolated knob east of the junction and south of the confluence of the White and Tweed Rivers, and in roadcuts at the Great Hawk housing development (not labeled on map) immediately north of the junction. Several thin greenstone bodies interlayered with the silvery green schist also are seen at the Great Hawk development. On the ridge east of Bartlett Brook, a minor unit of large-garnet schist ( $\mathrm{EZsgt)}$ is exposed as a thin layer within $€ Z \mathrm{Zs}$. To the south where the rocks of the Stowe Formation are within the garnet zone the large-garnet schist is a significant member of the formation (Walsh and Ratcliffe, 1994). North of the Rochester quadrangle, where the Stowe rocks are west of the garnet zone, the large-garnet schist is not a mappable unit (Cua, 1989; Kraus, 1989; Falta, 1991; Armstrong, 1992; Walsh, 1992).

Several thin layers of silvery green schist ( $€ Z s)$ have been mapped within the Ottauquechee Formation in the northeastern corner of the quadrangle. These layers are intercalated with the black phyllite (€ob) and are interpreted to be beds of Stowe-like rocks within the Ottauquechee, and therefore, have been mapped as Stowe $(\mathrm{\epsilon Zs})$. At least one of these layers (along the Bethel Mountain Road) maps into a belt of feldspathic schist with coticule ( $\mathrm{Gog}$ ) suggestive of an along strike facies change and perhaps indicating a stratigraphic link between the two formations in this area.

\section{Ultramafic Rocks}

Ultramafic rocks crop out in the Ottauquechee Formation or along faults between Ottauquechee and Stowe Formation rocks. Eight separate bodies were mapped; two in the town of Stockbridge in the southern part of the map area and six in the town of Rochester off the Bethel Mountain Road in the northern part of the map area. The ultramafic rocks consist mostly of carbonate-talc schist with lesser amounts of serpentine. The largest serpentine body is located on Cushman Hill 
(peak 2008 on the map, 400 m north of BM 1839 on the Bethel Mountain Road) where it is rimmed by carbonate-talc schist and chlorite blackwall. Thin greenstone and magnesitetalc granofels layers crop out within the deposit northwest of the village of Stockbridge, and the southern end of the ultramafic body terminates entirely within a greenstone. All the ultramafic bodies in the area mapped by Falta (1991) contain or are in close contact with greenstone, chlorite blackwall, and locally tremolite-chlorite schist. A coarse amphibolite consisting entirely of randomly oriented actinolite crops out between a serpentine and a greenstone $0.8 \mathrm{~km}$ northwest of the Bethel-Rochester town line on the eastern side of the Bethel Mountain Road. Jacobs (1914) reports such an actinolite gneiss in several places within the Williams mine located $1.4 \mathrm{~km}$ north of the Bethel-Rochester town line on the eastern side of the Bethel Mountain Road. This rock resembles a rock located entirely within an ultramafic body at Plymouth Five Corners (Walsh and Ratcliffe, 1994). Rusty carbonaceous and gray-green noncarbonaceous feldspathic schists also are associated with the ultramafic rocks. The ultramafic body west of the village of Stockbridge and $300 \mathrm{~m}$ southwest of peak 1838 consists entirely of carbonate-talc schist and is intercalated along thin $(<3 \mathrm{~m})$ zones parallel to the contacts of the Eocab rocks to the west and the Eogq rocks to the east.

Early interpretations on the origin of the ultramafic rocks in this area involved premetamorphic intrusion into the Ottauquechee rocks (Jacobs, 1914, 1918; Doll and others, 1961). Recent interpretations for the origin of similar ultramafic rocks in New England regard most of the rocks as fault slivers of oceanic crust and upper mantle (Stanley and others, 1984; Stanley and Ratcliffe, 1985). None of the ultramafic rocks in the Rochester quadrangle exhibits crosscutting relations indicative of an intrusive origin. Jacobs (1914) also noted that crosscutting relations were absent in quarry and mine exposures in the area, and that the contacts with the surrounding rocks were parallel to the schistosity, but still interpreted the rocks as intrusive. We believe that the interlayered contact relations and the presence of "exotic" rock types (greenstone, carbonaceous schist, feldspathic schist, and muscovite schist) within and adjacent to the ultramafic bodies support an olistostromal (block-in-matrix) origin for some of these rocks. Similar relations have been reported at the type locality of the Ottauquechee Formation in the Plymouth quadrangle (Walsh and Ratcliffe, 1994). All of the ultramafic bodies are highly deformed, however, and are cut and bounded by mylonitic fault fabrics. Our results do not support the interpretation that all of these rocks originated as pre-metamorphic fault slivers, but suggest that they may have a history of combined depositional and tectonic origin.

The ultramafic rocks have a history of economic significance in the Rochester area. Mining operations, largely for the extraction of talc, took place during the late 1800 's to early 1900's (Hitchcock and others, 1861; Jacobs, 1918). Serpentinite was also quarried on a smaller scale for verde antique marble (Jacobs, 1916). During the early 1900's when the Williams mine had the highest production in the State of Vermont, the resource potential was considered to be the largest in the world (Jacobs, 1918). A narrow gauge railroad, completed in 1913, connected the Williams mine with the McPherson mine and extended down along Rogers Brook to the main mill in Talcuille. The railroad has long since been abandoned, and not one of the mines or quarries is in operation today.

\section{LATE-METAMORPHIC AND POST-METAMORPHIC INTRUSIVE ROCKS}

\section{Granodioritic Dikes}

Seven outcrop-scale and one large map-scale granodioritic dikes intrude the greenstone and silvery green schist of the Pinney Hollow Formation. The dikes are informally referred to as the granodiorite at Liberty Hill. The rocks were quarried in the early 1900's, and the name Liberty Hill has been used in the literature to describe the quarry operations by the Liberty Hill Granite Company on Liberty Hill in Pittsfield (Dale, 1909, $1910,1923)$. The quarry is located approximately $100 \mathrm{~m}$ east of United States Forest Service Forest Road 229 (not labeled on map) from a point $0.5 \mathrm{~km}$ north of the junction with the Liberty Hill Road. The large dike measures approximately $150 \mathrm{~m}$ wide by $2,300 \mathrm{~m}$ long. Crosscutting relations, where xenoliths of the greenstone country-rock possess an older foliation, are exposed at outcrops $0.8 \mathrm{~km}$ north of the quarry on the eastern side of Forest Road 229.

Mineralogically the rock is a trondhjemite to granodiorite. The rock has a porphyritic texture with phenocrysts (as much as $3 \mathrm{~mm}$ long) of quartz and plagioclase in a quartz-plagioclase matrix. The rock possesses a weak foliation defined by the parallel growth of muscovite. An early description by Dale (1909) noted the foliated texture of the rock and the sheen imparted to the rock by the alignment of muscovite.

Earlier workers (Dale, 1915; Osberg, 1952; Falta, 1991) report similar dikes in the town of Hancock in the 7.5-minute Hancock quadrangle to the north. The granodiorite dikes are also similar to dikes in the Plymouth quadrangle (Chang and others, 1965; Walsh and Ratcliffe, 1994).

Structurally, the dikes cut an older penetrative foliation (Taconic $\mathrm{S}_{2}$ ), yet contain a weak foliation that is parallel to a regional crenulation cleavage in the western part of the quadrangle (Acadian $\mathrm{S}_{3}$ ). Ages of Acadian metamorphism of 385 to $375 \mathrm{Ma}$, based on ${ }^{40 \mathrm{Ar}} /{ }^{39} \mathrm{Ar}$ ages (Laird and others, 1984; Sutter and others, 1985), may approximate the age of the regional $\mathrm{S}_{3}$ foliation in the quadrangle. If this assumption is correct, the true age of the dikes must be between the time of the Taconian orogeny but before or during the Acadian deformation and metamorphism. These dikes are correlated with the Black Mountain Granite in southeastern Vermont. Ratcliffe and others (1997) report a U-Pb zircon age of $373 \pm 4 \mathrm{Ma}$ for the Black Mountain Granite, but report difficulties with ascertaining the age of a similar dike in the Plymouth quadrangle due to Middle Proterozoic inheritance. The dikes are, therefore, assigned a Devonian(?) age.

\section{Quartz Veins}

Quartz veins crop out in the Rochester quadrangle, and their locations are indicated with a strike and dip symbol that represents the average orientation of the generally tabular bodies. The mapped quartz veins are outcrop-scale and generally measure 1 to $2 \mathrm{~m}$ thick; smaller quartz veins are ubiquitous and have not been mapped. The veins are folded in places. Where the veins are folded they probably have a metamorphic origin. Tabular quartz veins postdate all the deformation and have either a late-metamorphic origin or a post-metamorphic igneous or a metasomatic origin. Anderson (1987) studied similar veins in north-central Vermont and concluded that most of the veins in the eastern cover sequence have a metamorphic origin, and 
that some (especially veins in northeastern Vermont) have a metasomatic origin related to New Hampshire series plutons. The veins, therefore, are assigned a Devonian and Ordovician(?) age.

\section{Lamprophyre Dikes and Hydrothermal Zone}

Four lamprophyre dikes $(\mathrm{Kd})$ and one saussuritized schist (Kds) are shown on the map. The dikes are the youngest rocks in the quadrangle. The dikes $(\mathrm{Kd})$ range in thickness from 0.5 to 1.5 $\mathrm{m}$ and generally intrude parallel to joint sets. A dolomite-quartzmuscovite-epidote schist (Kds) crops out in Corporation Brook and is interpreted as hydrothermally altered carbonaceous albite schist of the Fayston formation ( $€ Z \mathrm{fcab})$. The schist crops out in an approximately 2 -m-thick zone parallel to a joint set that strikes N. $64^{\circ} \mathrm{E}$., and dips $78^{\circ} \mathrm{SE}$. Walsh (1992) reports a similar rock at the Mad River Glen Ski Area in the town of Fayston. The lamprophyre dikes have been assigned a Cretaceous(?) age on the basis of the 122.2 $\pm 2 \mathrm{Ma}$ age of the intrusive complex at Ascutney Mountain (Foland and others, 1985) and on a regional summary by McHone (1984) for similar dikes throughout New England and Quebec. The origin of the hydrothermal zone also is assigned a Cretaceous(?) age based upon the zone's orientation parallel to a joint set and because the lamprophyre dikes generally intrude parallel to the regional joint sets.

\section{STRUCTURAL GEOLOGY}

\section{FOLIATIONS}

At least five distinct generations of foliation are present in the Rochester quadrangle. Stereographic projections of the three youngest foliations are shown in figure 2 (on plate); data on the two oldest foliations are not sufficient to plot.

The oldest foliation is the gneissic layering in the Middle Proterozoic Mount Holly Complex and was seen in only one outcrop in Townsend Brook in the Ymh unit. The oldest foliation in the eastern cover sequence $\left(S_{1}\right)$ is parallel to the oldest recognizable surface in these rocks, a compositional layering. This foliation is defined by the parallel arrangement of phyllosilicates along compositional boundaries. It is not sufficient to simply define this as the bed-parallel schistosity because younger deformational fabrics are also bed-parallel in places where the strain has reoriented all the layering into parallelism.

The second generation foliation in the cover sequence $\left(\mathrm{S}_{2}\right)$ is a penetrative schistosity that is the most conspicuous foliation in the quadrangle. In the western half of the quadrangle the $\mathrm{S}_{2}$ schistosity is everywhere the most visibly conspicuous foliation. Generally, the $\mathrm{S}_{2}$ foliation in the west strikes northwest and dips northeast (fig. 2B), and is only slightly deformed, mostly by later $F_{3}$ and, to a lesser extent, by $F_{4}$ folds. In the eastern half of the quadrangle the $\mathrm{S}_{2}$ schistosity varies from north-northwest striking and east-northeast dipping to an approximately east-west striking and steeply dipping schistosity that is slightly to highly deformed by the younger $F_{3}$ folds. Poles to $S_{2}$ in the east describe a great-circle that defines a $\pi$ pole, or $B$ fold axis, of $N$. $29^{\circ} \mathrm{E}$., $50^{\circ} \mathrm{NE}$. (fig. $2 \mathrm{C}$ ) that corresponds closely with the mean lineation of $F_{3}$ fold hinges, $S_{2}-S_{3}$ intersection lineations, and $L_{3}$ mineral-aggregate (quartz rods and chlorite streaks) lineations (fig. 2E, N. $28^{\circ} \mathrm{E}$., $57^{\circ} \mathrm{NE}$.). Mineral-aggregate lineations on $\mathrm{S}_{2}\left(\mathrm{~L}_{2}\right)$ and $\mathrm{F}_{2}$ fold hinges generally trend to the east-southeast and plunge moderately in the western part of the area (fig. 2B), but are re-oriented to the northeast in the east due to $F_{3}$ folding (fig. $2 \mathrm{C}$ ). Where the $\mathrm{L}_{2}$ lineation is visibly deformed by the $\mathrm{F}_{3}$ folds at the outcrop, a folded $\mathrm{L}_{2}$ lineation symbol indicates the approximate trend and plunge of the folded lineation.

The third generation foliation in the cover rocks $\left(\mathrm{S}_{2}\right)$ increases in intensity from west to east. In the west, $S_{3}$ is a north-striking, steeply dipping crenulation cleavage to spaced schistosity with an average strike and dip of N. $1^{\circ} \mathrm{E}$., $88^{\circ} \mathrm{SE}$. (fig. 2D). In the east, $S_{3}$ varies from a crenulation cleavage to a spaced schistosity to a penetrative schistosity associated with shear zones and faults. The average strike and dip of $S_{3}$ in the east $\left(N .10^{\circ} \mathrm{E}\right.$, $83^{\circ} \mathrm{SE}$.) differs little from that in the west. Generally, there is no mineral-aggregate lineation on the $S_{3}$ surfaces in the west because the foliation is not a penetrative schistosity. In the east, however, mineral-aggregate lineations $\left(L_{3}\right)$ are associated with $S_{3}$ where the foliation is a penetrative schistosity, especially in $S_{3}$ shear zones. The $\mathrm{L}_{3}$ lineations are also parallel to $\mathrm{F}_{3}$ fold hinges and $S_{2}-S_{3}$ intersection lineations in the east; the average trend and plunge is N. $28^{\circ} \mathrm{E}$., $57^{\circ} \mathrm{NE}$. (fig. $2 \mathrm{E}$ ).

The fourth generation foliation in the cover rocks $\left(S_{4}\right)$ is a spaced crenulation cleavage or spaced kink bands. The spacing between $\mathrm{S}_{4}$ foliation surfaces is several centimeters. The $\mathrm{S}_{4}$ foliation is most common in the eastern half of the quadrangle. The orientation of the $\mathrm{S}_{4}$ cleavage is variable but generally strikes to the northeast and dips northwest (fig. 2F). Locally, however, the $\mathrm{S}_{4}$ cleavage forms conjugate sets. The two poorly defined clusters of poles to $\mathrm{S}_{4}$ shown in figure $2 \mathrm{~F}$ are most likely the result of the conjugate nature of $\mathrm{S}_{4}$. Deformation by a later set of folds $\left(\mathrm{F}_{5}\right)$ cannot be ruled out, however, although no outcrop scale folds were observed.

\section{FOLDS}

At least four generations of folds are preserved in the cover rocks of the Rochester quadrangle. Due to the limited exposure of the basement, no folds associated with the Grenvillian gneissosity were observed.

$F_{1}$ folds whose axial surfaces correspond to the $S_{1}$ schistosity in the cover rocks occur in only two outcrops in the area, but have not been identified in map pattern. Where observed, the $F_{1}$ folds are rootless and isoclinal and have hinges that plunge parallel to later $F_{2}$ fold hinges. Because the $F_{1}$ folds are so rare and are not identified in map pattern they are the most enigmatic. It is possible that they represent either an early deformation that has subsequently been overprinted by the later deformation or that they are simply refolded, intrafolial $\mathrm{F}_{2}$ folds.

The second generation folds $\left(\mathrm{F}_{2}\right)$ are isoclinal reclined folds whose hinge lines plunge downdip to the east subparallel to the $\mathrm{L}_{2}$ lineations (fig. $2 \mathrm{~B}$ and $\mathrm{C}$ ). The $\mathrm{S}_{2}$ schistosity is parallel to the axial surface of $F_{2}$ folds. Locally, the $F_{2}$ folds are rootless and may even have a sheath fold geometry. Outcrop-scale $F_{2}$ sheath folds are most common in thin quartzites and coticules. Mapscale $\mathrm{F}_{2}$ folds are responsible for much of the distribution of rock types in the area.

The third generation folds $\left(\mathrm{F}_{3}\right)$ are upright, tight to open folds in the west and reclined, tight to isoclinal folds in the east. The $\mathrm{S}_{3}$ foliation is parallel to the axial surface of $\mathrm{F}_{3}$ folds. In the west, the $F_{3}$ folds warp and crenulate the $S_{2}$ schistosity. In the east, the $F_{3}$ folds are transposed in and near shear zones parallel to the $\mathrm{S}_{3}$ schistosity. The calculated average $\mathrm{F}_{3}$ fold hinge orientation is N. $2^{\circ} \mathrm{E} ., 18^{\circ} \mathrm{NE}$. in the west and N. $28^{\circ} \mathrm{E}$. $57^{\circ} \mathrm{NE}$. in the east where $\mathrm{F}_{3}$ and $\mathrm{L}_{3}$ are subparallel (fig. 2E). In the eastcentral part of the quadrangle, within the New Boston slice of the Ottauquechee Formation, the $\mathrm{F}_{3}$ folds deform the $\mathrm{S}_{2}$ folia- 
tion into a steeply dipping, east-west-striking foliation. This zone of east-west-trending $\mathrm{S}_{2}$ is named the New Boston antiform. North and south of the New Boston antiform the $\mathrm{F}_{2}$ and $F_{3}$ folds have subparallel axial surfaces where the $S_{2}$ and the $\mathrm{S}_{3}$ foliations are a composite schistosity. Figure 3 (on plate) shows two photographs and sketches of the outcrop-scale structural relations in the New Boston antiform. The New Boston antiform is bounded by faults and shear zones parallel to the $\mathrm{S}_{3}$ foliation and, therefore, represents a "megalithon" in the middle of the Ottauquechee Formation.

The fourth generation folds $\left(\mathrm{F}_{4}\right)$ are upright, open to tight folds and are most common in the eastern part of the quadrangle. The $\mathrm{S}_{4}$ foliation is parallel to the axial surface of $\mathrm{F}_{4}$ folds. The $\mathrm{F}_{4}$ folds may have a box fold geometry where the $\mathrm{S}_{4}$ cleavage is oriented in conjugate sets. The $\mathrm{F}_{4}$ fold hinges generally have a shallow north plunge (fig. $2 \mathrm{~F}$ ).

Figure 4 (on plate) shows three schematic block diagrams illustrating and summarizing the structural relations between the foliations and folds in the Rochester quadrangle.

\section{FAULTS}

The rocks of the eastern cover sequence are cut by a number of faults. The major faults in the quadrangle are parallel to the $\mathrm{S}_{2}$ and $\mathrm{S}_{3}$ schistosities. Faults in the western half of the quadrangle (see fig. 2, map, and cross sections) include the Thousand Acre Hill fault, the Darning Needle fault, and the Little Wilcox Peak fault. These three faults are parallel to the $\mathrm{S}_{2}$ schistosity in the western half of the map and are characterized by mylonitic foliations with pronounced downdip, east-southeast-trending lineations $\left(\mathrm{L}_{2}\right)$.

The Thousand Acre Hill fault is informally named for exposures on the summit of Thousand Acre Hill in the adjacent Mount Carmel quadrangle to the west. At Thousand Acre Hill gritty albite-quartz granofels $(€ \mathrm{Zt})$ of the Tyson Formation crops out on the western side of the summit and is structurally below interbedded carbonaceous albite schist ( $€ Z f c a b)$ and rusty muscovite schist ( $€ \mathrm{Zfrm})$ of the Fayston formation. The contact is parallel to the $\mathrm{S}_{2}$ foliation, and the Tyson and Fayston rock types are not interlayered. West of peak 2525 in the southwestern corner of the Rochester quadrangle, the $€ Z \mathrm{fcab}$ and $€ Z \mathrm{frm}$ units can be traced away from the Tyson contact across the southern slope of peak 2525 to a position east of the graygreen albite schist ( $€ Z f a b)$ of the Fayston formation on the eastern side of the peak. Here, the Fayston schists (€Zfcab, €Zfrm, and $€ Z f a b)$ are interbedded but the Tyson and Fayston rock types are not, and the contact between $€ Z$ fab and $€ Z t$ is sharp and parallel to $S_{2}$. As the contact is traced south into the northwestern corner of the Pico Peak quadrangle the lower plate Tyson granofels (€Zt) and the upper plate Fayston schists (€Zfab and $\left.€ Z f_{c} a b\right)$ are no longer found. Instead, basement rocks of the Mount Holly Complex ( $\mathrm{Ymh}$ and $\mathrm{Yq}$ ) are in sharp contact with the rusty muscovite schist (€Zfrm) of the Fayston formation. This evidence suggests the presence of an $\mathrm{S}_{2}$-generation fault that brings Fayston formation rocks over the Tyson Formation and Mount Holly Complex.

The Darning Needle fault is informally named for exposures located on a ridge north-northwest of the summit of the Darning Needle in the northwestern corner of the adjacent Pico Peak quadrangle. At an elevation of $2,500 \mathrm{ft}$ on the ridge, chloritemuscovite-quartz-plagioclase gneiss, feldspar augen gneiss, and quartzite of the Mount Holly Complex are found in an approximately 20-m-wide belt within the gray-green albite schist of the
Fayston formation (€Zfab). The belt of basement rocks and the albite schist can be traced, parallel to $S_{2}$, to the north-northwest into the Townsend Brook valley to a point just south of the Rochester quadrangle boundary. In the saddle between peaks 2388 and 2525 in the southwestern corner of the Rochester quadrangle, similar chlorite-muscovite-quartz-plagioclase gneiss and quartzite ( $\mathrm{Ymh}$ on the map) crop out along strike (parallel to $\mathrm{S}_{2}$ ) with the 20-m-wide belt from the Darning Needle area. Here, the basement rocks are in sharp contact with the rusty muscovite schist (€Zfrm) of the Fayston formation, and the rocks possess a mylonitic foliation with a pronounced southeasttrending lineation. These exposures of the Mount Holly Complex rocks are interpreted to be fault slivers along an $\mathrm{S}_{2}$ generation fault within the Fayston formation. North of the saddle the fault could not be traced with certainty, however, because the fault is bounded by the same rock types and no additional exposures of basement rocks were found.

The Little Wilcox Peak fault juxtaposes similar rocks of the Kings Pond and Mount Reeder belts of the Pinney Hollow Formation. The presence of the Wilcox Peak fault is equivocal, however, and its location is inferred from the distribution of map units. On Little Wilcox Peak albite schist (€Zphab) is interbedded with silvery green schist (€Zph). The albite schist can be traced southward into the headwater region of the Guernsey Brook valley. West of the albite schist (€Zphab) and a belt of silvery green schist (€Zph), a black carbonaceous schist (€Zphb) can be traced from the western side of Little Wilcox Peak into the western side of the Guernsey Brook valley. The €Zphab and $€ Z$ phb units are repeated on the eastern side of the Guernsey Brook valley suggesting a fold closure in the vicinity of ridge 1485 northwest of downtown Pittsfield. Along the 1485 ridge, however, only the eastern albite schist and carbonaceous schist crop out, and extensive exposures of silvery green schist from 1400 to $1800 \mathrm{ft}$ leave no room for the western limbs of such a fold. Chloritoid schist (€Zphc) and albite schist (€Zphab) to the west and greenstone ( $€ Z \mathrm{ph}$ ) to the east of the hypothetical fold axis are not repeated about the fold suggesting that if the fold were present it was not a quadrangle-scale fold (perhaps antithetic to the Mount Reeder fold), but a smaller scale fold instead with an apparent sheath fold geometry. The discontinuity of the units along the apparent axial surface of a transposed $\mathrm{F}_{2}$ fold suggests the presence of an intraformational fault between the Kings Pond and Mount Reeder belts. The presence of such a fault also explains the room problem south of Pittsfield between the greenstone and chloritoid units.

The total north-south extent of the Little Wilcox Peak fault is unknown, because the fault is parallel to the units away from the core of the transposed $F_{2}$ fold. Assuming the fault transposes a sheath fold with hinges that vary from $10^{\circ}$ to $20^{\circ}$ from the dip slip vector, a displacement estimate of 3 to $5 \mathrm{~km}$ is required to produce the map pattern. If such an offset is reasonable, it may be one factor that accounts for the dramatic thinning of the Pinney Hollow Formation south of the Rochester quadrangle.

In the eastern half of the map a number of faults and shear zones transpose or reorient the earlier $S_{2}$ foliation and $F_{2}$ folds; these faults are parallel to the $\mathrm{S}_{3}$ schistosity. The faults include the Tweed River fault, the White River fault, the Tupper fault, the Rogers Peak fault, and the Stockbridge-Rochester Gap fault system.

The Tweed River and White River faults are two faults that coincide approximately with the westernmost limit of penetrative $\mathrm{S}_{3}$ schistosity development in the quadrangle; both faults 
occur within the Pinney Hollow Formation. West of the faults the $\mathrm{S}_{3}$ foliation is generally an upright, nonpenetrative cleavage where $\mathrm{F}_{3}$ fold hinges plunge at shallow angles. East of the faults, however, the $S_{3}$ foliation varies from a penetrative schistosity with steep northeast-plunging fold hinges to a nonpenetrative cleavage. The area between and in the vicinity of the Tweed River and White River faults is a shear zone that represents a transition from predominantly $\mathrm{D}_{2}$ deformation in the west to $D_{2}$ overprinted by $D_{3}$ deformation to the east. Within, to the east, and locally to the west of the shear zone the $\mathrm{S}_{3}$ foliation transposes or reorients the $S_{2}$ foliation, and the resulting foliation is a composite $\mathrm{S}_{2}$ and $\mathrm{S}_{3}$ schistosity. Figure 5 (on plate) illustrates a composite $\mathrm{S}_{2}$ and $\mathrm{S}_{3}$ schistosity. The shear zone is illustrated on the map where the axial trace and limbs of the large $\mathrm{F}_{2}$ fold of Pinney Hollow greenstone in the Mount Reeder belt are progressively truncated from north to south, from west of Tupper to east of Pittsfield. In the south-central part of the map the Pinney Hollow rocks in the Emerson belt trend northeast-southwest subparallel to the $\mathrm{S}_{2}$ schistosity on the western side of South Hill, and are bounded by the Tweed River and White River faults. Exposures illustrating the fabrics associated with these faults and the shear zone are located in the following areas: (1) the southwesternmost slopes of South Hill, east of the Tweed River, at the latitude of the St. Dennis Church, (2) the eastern slopes and ridge of peak 2041, west of the White River, at the latitude of Tupper, (3) a roadcut along Route $100,0.3 \mathrm{~km}$ east of the bridge over Guernsey Brook, and the ridge north of the roadcut, (4) the western side of the summit of South Hill, and (5) at a gravel pit on the east side of Route 100, $1.5 \mathrm{~km}$ north of Tupper.

The Tupper fault juxtaposes rocks of the Pinney Hollow Formation to the west with rocks of the Ottauquechee Formation to the east. The fault is parallel to both the $\mathrm{S}_{2}$ and $\mathrm{S}_{3}$ schistosities and is characterized by a composite mylonitic to phyllonitic foliation. Earlier $\mathrm{F}_{2}$ fold hinges and $\mathrm{L}_{2}$ lineations observed in the vicinity of the fault are deformed by the $\mathrm{F}_{3}$ folds and reoriented parallel to the younger $F_{3}$ hinge lines. The subsequent transposition of $\mathrm{F}_{3}$ folds parallel to the $\mathrm{F}_{3}$ axial surfaces and $\mathrm{S}_{3}$ schistosity indicates fault activity during $\mathrm{D}_{3}$ deformation. Due to the penetrative $\mathrm{D}_{3}$ deformation it is difficult to determine the pre- $\mathrm{D}_{3}$ history of the fault. The subparallelism of $\mathrm{S}_{2}$ and $\mathrm{S}_{3}$ in the composite foliation suggests that the fault is either entirely a $D_{3}$ structure that transposes $S_{2}$ into parallelism, in which case $D_{2}$ motion is not required, or a reactivated $D_{2}$ structure that contained an $S_{2}$ foliation with a preexisting orientation similar to the subsequent $\mathrm{S}_{3}$. Sufficient data and observations of $\mathrm{L}_{2}$ fabrics associated with an earlier $D_{2}$ fault are lacking, however, and any earlier fault history is speculative. In addition to the structural arguments for the Tupper fault, the distribution of map units above and below the fault indicates low-angle truncation along virtually the entire length of the quadrangle. In the eastern part of the Emerson belt of the Pinney Hollow Formation, a feldspathic granofels unit $(€ Z$ phw) and a feldspathic quartz schist unit (€Zphq) are continuous from Talcville to Breakneck Brook. South of Breakneck Brook the two units are absent and are apparently truncated north of Tupper. Within the Ottauquechee Formation different units are present along the length of the fault from Rogers Peak southward to the quadrangle border, and again appear to end due to low-angle truncation. Exposures of the fault are located on the ridge immediately north and east of Tupper.

Despite the presence of a fault, there is a striking similarity between the black schist (€Zphb) and feldspathic quartz schist
(€Zphq) in the eastern part of the Pinney Hollow and the black phyllite (€ob) and the laminated feldspathic schist (€ogq) in the western part of the Ottauquechee, suggesting that the two formations may have originally had stratigraphic continuity.

The Rogers Peak fault juxtaposes rocks of the Rogers Peak and New Boston slices of the Ottauquechee Formation. Earlier $\mathrm{F}_{2}$ structures are truncated on the eastern side of the fault in the central part of the map. The fault is parallel to the $\mathrm{S}_{3}$ schistosity. Structural relations in the vicinity of the fault are similar to those along the Tupper fault. Exposures of the fault fabrics are located (1) north of Cold Brook, approximately $1.5 \mathrm{~km}$ northeast of Tupper, on the eastern side of an unnamed ridge between the 1,400- and 1,600-ft elevations and (2) in an unnamed stream valley, north of Route 100 , approximately 2.5 $\mathrm{km}$ east of Pittsfield along Route 100, between the 1,200- and 1,500-ft elevations.

The Stockbridge-Rochester Gap fault system corresponds to the main boundary between the Ottauquechee Formation to the west and the Stowe Formation to the east. The fault system is characterized by mylonitic foliation parallel to the $\mathrm{S}_{3}$ schistosity. Locally west of the fault system the $\mathrm{S}_{2}$ foliation is at high angles to the fault fabric. To the east in the Stowe Formation, however, the most visibly conspicuous foliation is a composite $S_{2}$ and $\mathrm{S}_{3}$ fabric parallel to the $\mathrm{S}_{3}$ schistosity. A similar structural relation exists in the Plymouth quadrangle along the Bald Mountain fault between the Ottauquechee and Stowe Formations (Walsh and Ratcliffe, 1994).

The Stockbridge-Rochester Gap fault system extends through Stockbridge in the southern part of the map and into the adjacent Bethel quadrangle to the east. The contact between the Stowe and Ottauquechee Formations is exposed at roadcuts at Rochester Gap on the Bethel Mountain Road just east of the Rochester quadrangle in the Bethel quadrangle. At the contact just west of the gap, a thin $(3 \mathrm{~m})$ sliver of black phyllite is exposed in an oblique cross sectional roadcut. The boundaries of the sliver are parallel to the $\mathrm{S}_{3}$ schistosity, yet internally the sliver contains highly contorted $\mathrm{S}_{2}$ foliation with refolded $\mathrm{F}_{2}$ folds of thin quartzite layers. To the east of the sliver, in the Stowe Formation rocks, the $\mathrm{S}_{3}$ foliation is a penetrative mylonitic foliation that dips steeply to the west and is deformed by later westdipping $\mathrm{F}_{4}$ folds. In the Ottauquechee Formation west of the sliver, the rocks consist of both black phyllite and silvery green schist that are locally so well interlayered and highly contorted that much of the original layering must be primary. This layering is an outcrop-scale analog of the interlayered $€ Z s$ and $€$ ob units along and to the west of the Bethel Mountain Road in the Rochester quadrangle. Locally in the mixed silvery green and black rocks, shear zones are parallel to both the $\mathrm{S}_{2}$ and $\mathrm{S}_{3}$ foliations. In the cuts west of the black phyllite sliver to the Rochester-Bethel town line, $\mathrm{S}_{3}$ varies from a crenulate cleavage to a penetrative shear zone schistosity. Although not continuous with the Stockbridge-Rochester Gap fault system, a series of unnamed interconnected faults, located in the vicinity of the Williams mine along the Bethel Mountain Road, possesses similar fault fabrics.

Within the New Boston slice of the Ottauquechee Formation there are a couple of small faults that are parallel to the $S_{3}$ foliation. These faults have relatively small offsets and may have both thrust (or reverse) and normal displacement senses based on relations seen in outcrop. In figure 3 , small slip surfaces (or faults) parallel to the $S_{3}$ cleavage cut the quartzite layering. The displacement senses of the small faults are both normal and 
reverse. The dip of the $\mathrm{S}_{3}$ foliation in the area is fairly consistent and dips both steeply to the east and west. The steep orientation of these faults combined with the normal and reverse displacement senses suggests these faults accommodated flattening strain normal to the $S_{3}$ foliation during the $D_{3}$ event, rather than translation on the faults.

Where the contact between the Stowe and Ottauquechee or Pinney Hollow and Ottauquechee Formations does not coincide with the Stockbridge-Rochester Gap fault system or the Tupper fault, the contact relations are more cryptic. In the south-central part and the northeastern corner of the mapped area, finegrained silvery green schist of the Stowe $(€ Z s)$ and Pinney Hollow (€Zph) are mapped within the New Boston slice of the Ottauquechee Formation. Locally the black phyllite (€ob) contains thin layers of silvery green to rusty yellow-weathering noncarbonaceous schist that are too small to map separately; these layers are lithically similar to the $€ Z$ s and $€ Z$ ph units. Roadcuts along the Bethel Mountain Road at the Rochester-Bethel town line illustrate the delicate interlayering of the carbonaceous and noncarbonaceous rock types. This type of interlayering typically occurs near the eastern and western contacts of the Ottauquechee Formation. Some of the thin mappable bodies of $€ Z s$ in the northeastern corner of the map exhibit this interlayering and are believed to be interbedded Stowe rocks within the Ottauquechee. Several larger mappable bodies of $€ Z s$ and $€ Z p h$, however, do not clearly exhibit interlayered contacts, and they appear to (1) be discordant at low angles with the Ottauquechee rocks and (2) predate $\mathrm{F}_{2}$ folding. The contacts of these units with the Ottauquechee have been mapped as conjectural premetamorphic thrust faults. The displacement sense on these conjectural early faults is unknown. Detailed mapping (1:12,000) to the north (Kraus, 1989; Falta, 1991; Armstrong, 1992) suggests upper and lower plate truncations along similar contacts. Truncations of units within $€ Z \mathrm{ph}$ and $€ Z \mathrm{~s}$ shown as fault-bounded on this map cannot be demonstrated unequivocally, so the fault nature of the contact is more speculative than the work to the north. The premetamorphic fault interpretation does not explain why beds and layers similar to Pinney Hollow and Stowe rocks are found in the western and eastern parts of the Ottauquechee. The presence of these interlayered rocks in the Ottauquechee suggests that, in this map, some of the Stowe and Pinney Hollow rocks had stratigraphic continuity with the Ottauquechee Formation, but does not preclude the possibility that the distribution of some units may be explained by premetamorphic faulting. Despite the equivocal nature of the early contacts, this map demonstrates that most of the formational boundaries in the quadrangle are faults that are parallel to the metamorphic fabrics. This explains why the general trend of the formations is parallel to the strike of the regional foliation yet internal members are highly folded.

\section{METAMORPHISM}

Rocks of the Mount Holly Complex experienced hornblendegranulite facies metamorphism during the Middle Proterozoic Grenville orogeny and extensive retrogression in later Paleozoic events (Doll and others, 1961; Sutter and others, 1985). The regional metamorphic grade attained during the Paleozoic Taconic and Acadian orogenies ranges from biotite grade in the west to garnet grade in the east. In general, the higher grade rocks to the east have been affected by Acadian metamorphism that occurred relatively late in the structural history. In the west- ern part of the area a well-developed foliation $\left(\mathrm{S}_{2}\right)$ expressed by lepidoblastic and fine-grained muscovite, chlorite, and biotite formed synchronous with $\mathrm{D}_{2}$ thrust faults and deformation. This period of metamorphism is believed to have occurred during the Taconic orogeny in the Medial and Late Ordovician (Laird and others, 1984; Sutter and others, 1985). In the central and eastern part of the quadrangle where the $S_{3}$ foliation is a penetrative schistosity, it is defined by lepidoblastic muscovite and chlorite. Biotite that is parallel to the $\mathrm{S}_{2}$ foliation is retrograded to chlorite during the development of $\mathrm{S}_{3}$. Locally in the west, and widespread in the east, static-overgrowth porphyroblasts of muscovite, chloritoid, and biotite postdate the $\mathrm{S}_{2}$ and $\mathrm{S}_{3}$ foliations. Locally in the east static-overgrowth porphyroblasts of garnet postdate both the $S_{2}$ and $S_{3}$ foliations. Small $(<2 \mathrm{~mm})$ idioblastic garnet porphyroblasts occur in the east and include planar $S_{3}$ inclusion trails that are, locally, slightly warped by the $\mathrm{S}_{4}$ cleavage (the symbol "Gt" on the map shows the locations where these garnets are visible in the outcrop). The axial surfaces of the minor $\mathrm{S}_{4}$ crenulations in the matrix are coplanar with similar but subdued plications in these small garnets. Chlorite pseudomorphs with garnet cores are present locally in the coarse-muscovite schist ( $\mathrm{Eom}$ ) of the Ottauquechee Formation and the silvery green schist (€Zs) and garnet schist (€Zsgt) of the Stowe Formation. The pseudomorphs are generally euhedral and maintain the shape of the garnet porphyroblast; locally however the pseudomorphs are slightly elongate in the plane of the $\mathrm{S}_{3}$ foliation, parallel to the $\mathrm{S}_{3}-\mathrm{S}_{4}$ intersection, and may be slightly warped by the $\mathrm{S}_{4}$ cleavage. The late porphyroblasts are interpreted as Acadian (Laird and others, 1984).

Regarding Paleozoic metamorphism, the petrographic and structural evidence indicates that an early phase of metamorphism reached at least to the biotite zone during the development of the $\mathrm{D}_{2}$ fabrics. The rocks were then subjected to a retrograde event in the chlorite zone during the development of the $\mathrm{D}_{3}$ structures. A subsequent prograde metamorphic event reached the garnet zone in the east and peaked during and after the development of the $\mathrm{D}_{4}$ fabrics. The early biotite zone metamorphism is interpreted as a peak Taconian event, the late garnet zone metamorphism as a peak Acadian event, and the timing of chlorite zone retrogression must be either late Taconian or early Acadian.

\section{REFERENCES CITED}

Anderson, J.R., 1987, Metamorphic veins in the Paleozoic rocks of central and northern Vermont, in New England Intercollegiate Geological Conference, 79th Annual Meeting, Montpelier, Vt., Oct. 16-18, 1987, Guidebook for field trips in Vermont, v. 2: Northfield, Vt., Norwich University, Department of Earth Sciences, p. 133-151. (Edited by D.S. Westerman.)

Armstrong, T.R., 1992, Tectonostratigraphic geology of the Granville-Hancock area, central Vermont: Burlington, Vt., University of Vermont, unpublished M.S. thesis, $189 \mathrm{p}$., scale $1: 12,000$.

Brace, W.F., 1953, The geology of the Rutland area, Vermont: Vermont Geological Survey Bulletin 6, 120 p., scale 1:62,500.

Cady, W.M., 1956, Bedrock geology of the Montpelier quadrangle, Vermont: U.S. Geological Survey Geologic Quadran-gle Map GQ-79, scale 1:62,500.

Cady, W.M., Albee, A.L., and Murphy, J.F., 1962, Bedrock geology of the Lincoln Mountain quadrangle: U.S. 
Geological Survey Geologic Quadrangle Map GQ-164, scale 1:62,500.

Cady, W.M., Albee, A.L, Chidester, A.H., 1963, Bedrock geology and asbestos deposits of the Upper Missisquoi valley and vicinity. Vermont, Contributions to Economic Geology: U.S. Geological Survey Bulletin 1122-B, 78 p.

Chang, P.H., Ern, E.H., Jr., and Thompson, J.B., Jr., 1965, Bedrock geology of the Woodstock quadrangle, Vermont: Vermont Geological Survey Bulletin 29, 65 p., scale 1:62,500.

Christman, R.A., and Secor, D.T., 1961, Geology of the Camels Hump quadrangle, Vermont: Vermont Geological Survey Bulletin 15, 70 p., scale 1:62,500.

Coish, R.J., 1987, Regional geochemical variations in greenstones from the central Vermont Appalachians, in New England Intercollegiate Geological Conference, 79th Annual Meeting, Montpelier, Vt., Oct. 16-18, 1987, Guidebook for field trips in Vermont, v. 2: Northfield, Vt., Norwich University, Department of Earth Sciences, p. 345-350. (Edited by D.S. Westerman.)

Coish, R.J., Fleming, F.S., Larsen, M., Poyner, R., and Seibert, J., 1985. Early rift history of the proto-Atlantic Ocean; Geochemical evidence from metavolcanic rocks in Vermont: American Journal of Science, v. 285, p. 351-378.

Coish, R.J., Perry, D.A., Anderson, C.D., and Bailey, D., 1986, Metavolcanic rocks from the Stowe Formation, Vermont; Remnants of ridge and intraplate volcanism in the Iapetus Ocean: American Journal of Science, $v$. 286, p. 1-28.

Cua, A.K., 1989, Geology and geochemistry of metabasaltic rocks from the Roxbury area, central Vermont: Burlington, Vt., University of Vermont, unpublished M.S. thesis, 256 p., scale 1:12,000.

Dale, T.N., 1909, The granites of Vermont: U.S. Geological Survey Bulletin 404, 138 p.

1910, The granites of Vermont: Vermont State Geologist's 7th Report (1909-1910), p. 78-199.

1915, The calcite marble and dolomite of eastern Vermont: U.S. Geological Survey Bulletin 589, 67 p.

- _ 1923, The commercial granites of New England: U.S. Geological Survey Bulletin 738, 488 p.

DelloRusso, Vincent, and Stanley, R.S., 1986, Geology of the northern part of the Lincoln massif, central Vermont: Vermont Geological Survey Special Bulletin 8,56 p., scales $1: 12,000$ and 1:24,000.

DiPietro, J.A., 1983, Geology of the Starksboro area, Vermont: Vermont Geological Survey Special Bulletin 4, 14 p., scale 1:24,000.

Doll, C.G., Cady, W.M., Thompson, J.B., Jr., and Billings, M.P., comps. and eds., 1961, Centennial geologic map of Vermont: Montpelier, Vermont Geological Survey, scale 1:250,000.

Falta, C.K., 1991, Tectono-stratigraphic geology of the Rochester-Hancock area, Rochester quadrangle, central Vermont: Burlington, Vt., University of Vermont, unpublished M.S. thesis, 223 p., scale 1:12,000.

Foland, K.A., Henderson, C.M.B., and Gleason, James, 1985, Petrogenesis of the magmatic complex at Mount Ascutney, Vermont, USA; I. Assimilation of crust by mafic magmas based on $\mathrm{Sr}$ and $\mathrm{O}$ isotopic major ele- ment relationships: Contributions to Mineralogy and Petrology, v. 90, p. 331-345.

Foye, W.C., 1918, A report on the geological work within the Rochester, Vermont quadrangle: Vermont State Geologist's 11th Report (1917-1918), p. 76-98.

Hitchcock, Edward, Hitchcock, E.J., Hager, A.D., Hitchcock, C.H., 1861, Report on the geology of Vermont: Claremont, New Hampshire, 982 p.

Jacobs, E.C., 1914, Talc, and the talc deposits of Vermont: Vermont State Geologist's 9th Report (1913-1914), p. 382-429.

1916, The talc and verd antique deposits of Vermont: Vermont State Geologist's 10th Report (1915-1916), p. 232-280.

1918, Progress in talc production: Vermont State Geologist's 11th Report (1917-1918), p. 148-157.

Kraus, J.F., 1989, Geology of the Northfield Mountains, central Vermont: Burlington, Vt., University of Vermont, unpublished M.S. thesis, 145 p., scale 1:12,000.

Kumarapeli, P.S., Dunning, G.R., Pinston, H., and Shaver, J., 1989, Geochemistry and U-Pb zircon age of comenditic metafelsites of the Tibbit Hill Formation, Quebec Appalachians: Canadian Journal of Earth Sciences, v. 26, p. 1374-1383.

Laird, Jo, Lanphere, M.A., and Albee, A.L., 1984, Distribution of Ordovician and Devonian metamorphism in mafic and pelitic schists from northern Vermont: American Journal of Science, v. 284, p. 376-413.

Lapp, E.T., and Stanley, R.S., 1986, Bedrock geology of the Mt. Grant-South Lincoln area, central Vermont: Vermont Geological Survey Special Bulletin 7, 27 p., scale $1: 12,000$.

McHone, J.G., 1984, Mesozoic igneous rocks of northern New England and adjacent Quebec; Summary, description of map, and bibliography of data sources: Geological Society of America Map and Chart Series MC-49, scale 1:690,000.

O'Loughlin, S.B., and Stanley, R.S., 1986, Bedrock geology of the Mt. Abraham-Lincoln Gap area, central Vermont: Vermont Geological Survey Special Bulletin 6, 29 p., scale 1:12,000.

Osberg, P.H., 1952, The Green Mountain anticlinorium in the vicinity of Rochester and East Middlebury, Vermont: Vermont Geological Survey Bulletin 5, 127 p., scale 1:62,500.

Perry, E.L., 1927, Summary report on the geology of Plymouth and Bridgewater, Vermont: Vermont State Geologist's 15th Report (1925-1926), p. 160-162.

1929, The geology of Plymouth and Bridgewater townships, Vermont: Vermont State Geologist's 16th Report (1927-1928), p. 1-64.

Potter, D.B., 1972, Stratigraphy and structure of the Hoosac Falls area, New York-Vermont, east-central Taconics: New York State Museum and Science Map and Chart Series $19,71 \mathrm{p}$.

Ratcliffe, N.M., 1992, Preliminary bedrock geologic map of the Mount Holly quadrangle and portions of the Ludlow quadrangle, Rutland and Windsor Counties, Vermont: U.S. Geological Survey Open-File Report 92-282-A, scale 1:24,000.

-1995. Changes in stratigraphic nomenclature in the eastern cover sequence in the Green Mountain massif 
from Ludlow to West Bridgewater, Vermont, in Changes in Stratigraphic Nomenclature for 1993: U.S. Geological Survey Bulletin 2060, p. 1-10.

Ratcliffe, N.M., and Walsh, G.J., 1998, Digital and preliminary bedrock geologic map of the Mount Carmel 7.5 by 15 minute quadrangle, Vermont: U.S. Geological Survey Open-File Report 98-330-A, scale 1:24,000.

Ratcliffe, N.M., Aleinikoff, J.N., Burton, W.C., and Karabinos, P.A., 1991, Trondhjemitic, 1.35-1.31 Ga gneisses of the Mount Holly Complex of Vermont; Evidence for an Elzevirian event in the Grenville basement of the United States Appalachians: Canadian Journal of Earth Sciences, v. 28, p. $77-93$.

Ratcliffe, N.M., Walsh, G.J., and Aleinikoff, J.N., 1997, Basement, metasedimentary and tectonic cover of the Green Mountain massif and western flank of the Chester dome, in Grover, T.W., Margo, H.N., and Hasenohr, E.J., eds., Guidebook to field trips in Vermont and adjacent New Hampshire and New York: New England Intercollegiate Geological Conference, 89th Annual Meeting, KillingtonPico region, Vt., Sept. 19-21, 1997, p. C6-1-C6-54.

Ratcliffe, N.M., Harris, A.G., and Walsh, G.J., 1999, Tectonic and regional metamorphic implications of the discovery of Middle Ordovician conodonts in cover rocks east of the Green Mountain massif, Vermont: Canadian Journal of Earth Sciences, v. 36, no. 3, p. 371-382.

Rowley, D.B., Kidd, W.S.F., and Delano, L.L., 1979, Detailed stratigraphic and structural features of the Giddings Brook slice of the Taconic allochthon in the Granville area, in New England Intercollegiate Geological Conference, 71st Annual Meeting, and New York State Geological Association, 51st Annual Meeting, Troy, N.Y., Oct. 5-7, 1979, Guidebook: Troy and Albany, N.Y., Rensselaer Polytechnic Institute and New York State Geological Survey, p. 186-242. (Edited by G.M. Friedman.)

Stanley, R.S., Roy, D.L., Hatch, N.L., Jr., and Knapp, D.A., 1984, Evidence for tectonic emplacement of ultramafic and associated rocks in the pre-Silurian eugeoclinal belt of western New England; Vestiges of an ancient accretionary wedge: American Journal of Science, v. 284, p. 559-595.

Stanley, R.S., and Ratcliffe, N.M., 1985, Tectonic synthesis of the Taconic orogeny in western New England: Geological Society of America Bulletin, v. 96, p. 1227-1250.

Stanley, R.S., DelloRusso, Vincent, O'Loughlin, Sharon, Lapp, Eric, Armstrong, T.R., Prewitt, Jeffrey, Kraus, J.F., and
Walsh, G.J., 1987, A transect through the pre-Silurian rocks of central Vermont, in New England Intercollegiate Geological Conference, 79th Annual Meeting, Montpelier, Vt., Oct. 16-18, 1987, Guidebook for field trips in Vermont, v. 2: Northfield, Vt., Norwich University, Department of Earth Sciences, p. 272-295. (Edited by D.S. Westerman.)

Sutter, J.F., Ratcliffe, N.M., and Mukasa, S.B., 1985, ${ }^{40} \mathrm{Ar} /{ }^{39} \mathrm{Ar}$ and $\mathrm{K}-\mathrm{Ar}$ data bearing on the metamorphic and tectonic history of western New England: Geological Society of America Bulletin, v. 96, p. 123-136.

Tauvers, P.R., 1982, Bedrock geologic map of the Lincoln Mountain area, Vermont: Vermont Geological Survey Special Bulletin 2, 8 p., scale 1:24,000.

Thompson, P.J., and Thompson, T.B., 1992, Bedrock geology of the Camels Hump-Bolton Mountain area, north central Vermont: Vermont Geological Survey Special Bulletin 12, 32 p., scale 1:24,000.

Walsh, G.J., 1989, Tectonic geology of the Fayston-Waitsfield area, central Vermont: Burlington, Vt., University of Vermont, unpublished M.S. thesis, 224 p., scale 1:12,000. 1992, Bedrock geology of the Fayston-Buels Gore area central Vermont: Vermont Geological Survey Special Bulletin 13, scale 1:24,000.

Walsh, G.J., and Aleinikoff, J.N., 1999, U-Pb zircon age of metafelsite from the Pinney Hollow Formation; Implications for the development of the Vermont Appalachians: American Journal of Science, v. 299, p. 157-170.

Walsh, G.J., and Ratcliffe, N.M., 1994, Preliminary bedrock geologic map of the Plymouth quadrangle and eastern portion of the Killington Peak quadrangle, Windsor and Rutland Counties, Vermont: U.S. Geological Survey OpenFile Report 94-225-A, scale 1:24,000.

Walsh, G.J., and Ratcliffe, N.M., 1998, Digital and preliminary bedrock geologic map of the Pico Peak quadrangle, Vermont: U.S. Geological Survey Open-File Report 98-226-A, scale 1:24,000.

Walsh, G.J., and Stanley, R.S., 1988, Tectonic lithostratigraphic units of the Camels Hump Group in the vicinity of Fayston, Vermont [abs.]: Geological Society of America Abstracts with Programs, v. 20, no. 1, p. 76.

Zen, E-an, 1967, Time and space relationships of the Taconic allochthon and autochthon: Geological Society of America Special Paper 97, 107 p. 

